\title{
A CASE STUDY OF AN EXPANSION OF INDIAN FOREIGN POLICY TOWARDS EAST ASIA: LOOK EAST POLICY TO ACT EAST POLICY
}

\author{
Mr. Kashyap Kotecha \\ \& \\ Dr. Mukesh Khatik
}

\section{Abstract:}

Foreign policies of the Nation-States being corrected continuously, especially after the Post - Cold war multipolar scenario. India's partnership with SouthEast Asian Nation-States is a Post - Cold war story. The era of globalisation impels India as well as ASEAN countries to explore opportunities for mutual economic and strategic benefits, as a result of that India adopted the Look East Policy during 1990. Look East Policy being implemented successfully by successive governments.

Meanwhile, China is being emerged as a global economic superpower in the last two decades. Due to the rise of Chinese hegemony in the South-East Indian and Indo-Pacific region compel India and other stack holder countries to reshape their foreign policies according to time, to serve their national interests.

Consequently, the last Indian Government redefined and renamed the Look East policy to Act East Policy. One could say it as an updated version of Look East policy. In earlier episode policy was limited to South East Asia while in next episode focus of the policy is on whole East Asia. Also, the scope of Look East policy was idealistic and economic-centred, while the scope of the Act East Policy is realistic and vast. The newly emerged Act East Policy has an extra strategic edge over previous Look East Policy, the newer version is multidimensional, and it inculcates the strategic vision like the balance of power in East Asia, national interest and security-related issues in addition to the economic vision. Indeed, the nature of foreign policy always should be dynamic rather than static; hence, the Indian foreign policy is being transformed continuously as per the requirement of the time. 
Keywords: [Indian foreign policy, Post-Cold war, Multipolar world, East Asia, South East Asia, Look East Policy, Act East Policy, National interest]

\section{Introduction:}

After independence, Embryonic foreign policy of India shaped under the idealistic influence of India's first prime minister Lt.Pandit Jawaharlal Nehru. Due to the utopian and idealistic inclination of Lt. Pandit Nehru, India has a considerable amount of reluctance toward Realism. Although during the NonAlignment movement, Nehru's foreign policy had a greater connection with South-East Asian countries, the focal point of Nehru's policy was more ideological rather than realistic and strategical. Nehru's speculation towards Idealism had fallen apart after India's loss against the Indo-Sino war - 1962. Since then China and India are strategic corivals in South and East Asia region. Before introducing the Act East Policy in 1991,The period between Post-1947 and Pre-1991 Indian foreign policy had passed through 'Blinder era' towards the South-East Asia region.Before disintegration of U.S.S.R India made exiguous efforts to stimulate vicinal relationship with the governments of South East Asia. One could deduce a few substantive reasons behind that geopolitical stance. First, due to colonial chronology. Mainly Post-1947, India's ruling gentry had an enormous amount of orientation towards Western Anglo-Saxon Powers. Obviously, they were economically more developed than India's neighbours. The ideological stance of Nehru kept less impact on India's neighbourhood. Second, India's entrance towards South East Asia was precluded by Myanmar's isolationist policies. Also, Bangladesh reluctance to provide en route through its territory. Third, India and South-East Asian NationStates were antithetical during Cold war bisection.

\section{Transformation of China during the 'Blinder era of India' towards the South-East Asian region:}

Due to India's lake of heed to establish reasonable relations with South-East Asian Nations-States and disintegration of U.S.S.R put a door ajar for China to enter and influence the South-East Asian region. Consequently, China took allembracing advantage of a vulnerable situation. During Deng Xiaoping's leadership epoch in 1979, China superseded its policy of expansionism with promulgating to cultivate trade and economic relations with South-East Asian 
nations. During that phase, Burma had been excommunicated with Internation community because of violent subjugation of Pro-Democratic activities; China took its advantage and became close playmate of Burma by supporting the Military Junta movement in Burma.Former Indian Ambassador Rajiv Sikri noted

"India missed a crucial opportunity during this period to leverage India's shared colonial experience, cultural affinities and lack of historical baggage to build strong economic and strategic relations with Southeast Asia".

India's lake of heed to connect Southeast Asia during this era put China in the driver seat in the South-East Asian region.

\section{Post - 1990, Commencement of Look East Policy Era}

During 1991, India passed through the economic crisis that coexisted with the disintegration of U.S.S.R., which was Indias most trusted strategic and economic partner for an extended period. Throughout that period Government of India was being headed by Prime Minister Lt. Narshimha Rao. The newly emerged situation necessitated the government to reevaluate the foreign policy of India. Consequently, two significant changes in India's foreign policy came out as a reflection of obnoxious Eco-Political circumstances. First, India superseded its protective economic policy with more liberal policy, by opening the higher levels of trade and seeking to multiply the regional market. Second, India commenced recognising South Asia as a particular compartment.

Myanmar is only South Asian country that has an adjacent territory with India. Myanmar is always seenas the gateway to connectivity with South Asian countries by India. Due to the result of Look east policy, back in 1993, India conversely adopted a policy of support for Myanmar's pro-democracy by cultivating the friendship of ruling military junta. Since that time, the Indian government and some of the private corporations gained well-worth contracts for building industrial and infrastructure projects, including port and highways. Hitherto execution of Look East policy China alone gaining benefits from Myanmar's vast oil and natural gas fields.

Additionally, while China remains the biggest provider of arms to Myanmar, India has augmented its military synergy with Myanmar. India increased its cooperation in intelligence and military affairs with Myanmar to annihilate the 
established insurgents from the common border in betweenNorthEasternprovinces of India and Myanmar.

Since 2003, India has launched the crusade to advance free trade agreements toward the South-East Asian region. The South-East Asia Free Trade Agreement generated Free Trade area of 1.6 billion people across the region including Bangladesh, Bhutan, India, Maldives, Nepal, Pakistan and Sri Lanka. The Free Trade Agreement came in to force since 2006. The ASEAN free trade area (AIFTA) are among the ASEAN countries came into effect since 2010. India has also forged distinct trade agreements with Sri Lanka, Japan, South Korea, Singapore, Thailand and Malaysia. India also enhanced synergy with Asian regional groupings like Bay of Bengal Initiative Multi-Sectoral Technical and Economic cooperations (BIMSTEC) and South Asian Association for Regional Cooperation. Apex level of diplomatic meetings among the associate regional partners became frequent in the last decade.

Former Prime Minister of India announced many bilateral initiatives and signed dozens of MOU during his visit to Myanmar in 2012. In addition to that, he extended a credit line to $\$ 500$ million. Some of the significant projects commenced and incorporated by India, like upgrading the Tamu-KalewaKalemyo road and Kalandan project to connect Kolkata port with Sittwe Port of Myanmar. In conclusion, one can say Look East Policy appended the chapter of sheer economic relations with South-East Asian countries.

\section{Post - 2014, Act East Policy Era}

Newly upgraded avatar of Look East Policy was being transformed into Act East Policy by newly elected Government of India headed by Prime Minister Narendra Modi in 2014, had shown sheer importance towards the South East and East region. NDA government upgraded the Look East Policy to Act East Policy during East India Summit held at Myanmar in November 2014. After the retrospection of India's foreign policy towards South East Asia, the new government attempted to add more dimensions to the previous one. Look East Policy seemed to have a fractional or single-dimensional approach. The previous policy only contained the 'Economic Dimension', while Act East Policy came out with a more integral approach or multi-dimensional approach. The focal point of Look East Policy was to strengthen the economic integration with South-East Asian countries, and the sphere was just restricted to South East Asia only, While in Act East Policy focal point is expanded, It includes the 
economic and security integration and enlarged its sphere from South East Asia to East Asia. Act East Policy is appended by four core objectives to revitalise India's economic, security and cultural concerns. First, the new avatar of the policy shall promote economic cooperation, cultural links and develop strategic relations with countries in the Indo-Pacific region with continuous sponsalia at the regional, bilateral and multilateral level. Second, to strengthen the reciprocity of the North-Eastern states of India with other neighbouring countries. Third, to search out the alternative of the orthodox business partners, such as more focus on Pacific countries in addition to South Asian countries. Fourth, As per the experts, under the Act East Policy India reckons more upon $3 \mathrm{C}$ 'S - Culture, Connectivity and Commerce. In order to reap the benefits of Act India Policy, India has ameliorated its relations with Japan, Australia, Vietnam, Indonesia, Malaysia, Republic of Korea and ASEAN and moulded close ties with all countries in Indo-Pacific region. Apart from that, India is also connected in regional forums like Indian Ocean Rim Association (IORA), Bay of Bengal Initiatives for Multi-Sectoral Technical and Economic Cooperation (BIMSTEC),Asia Cooperation Dialogue (ACD) and Mekong Ganga Cooperation (MGC).

Two projects are going on to improve the connectivity of India with South East Asia. First, India-Myanmar-Thailand Trilateral Highway,running from Moreh in Manipur state in Northeast India to Mae Sot in Thailand passing through Myanmar,which might extend to Laos and Cambodia.Second, Kaladan MultiModal Transit Transport Project, which connects India's state Mizoram with rest of India as well as South-East Asia.

During Global Investor Summit held at Guwahati in February 2018, Prime minster of India Narendra Modi expounded India's Northeast region as at the heart of the Act East Policy. Prime minister also coined 'Advantage Assam: India's gateway to ASEAN' as a tag line of the summit.

By learning through retrospection, India's foreign policy has been developing since independence, recently transiting through an advance phase, where connectivity and cultural ties getting matured.

\section{Epilogue}

If one goes by the history of India's foreign policy, one will find four different eras of India's foreign policy. Post-1947, Immediately after independence, Indian foreign policy was dominated by a utopian ideological era, where India had relations with South-East Asian countries up to some extent, but it was 
purely on an ideological basis. The second phase was dominated by Indira Gandhi's hyper-realistic policy, where India created asymmetry that pushes other smaller South-East Asian neighbour countries into suspecting hegemony by India, that did not allow them to trust India. Post-1990, in the third phase, the government headed by P.V Narsihmarao rectified past geopolitical gaffe and demonstrated a broader focus towards South East Asia, and the government came out with policy called 'Look East Policy', that much focused on strengthening the economic relations with immediate South East Asian neighbourhood. Later in the same phase, the Minister of External Affairs I.k Gujral came out with 'Gujaral Doctrine' to improve cordial relations with country's neighbours, it added higher value to Look East Policy, but it was again more ideological and less strategical. Post- 2014, in the fourth and ongoing phase of India's foreign policy, newly elected N.D.A government emerged with a more integral approach; It added a strategic and cultural dimension to existing Look East Policy, furthermore government expanded its geopolitical reach by appending the extra dimension called 'Focus will not be only in South East Asia, but it will be on whole East Asia'. Moreover, named previous Look East Policy as Act East Policy, and attempted to make it more 'Action-oriented' rather than 'Idea-oriented'.

By attempting assiduously to connect more with the Eastern Neighbourhood, India is not supposed to ignore the maritime strategic dimension, India needs to focus on maritime strategy for future perspective to deal with Chinese hegemony. Throughout the decade the Indian Navy budget has stuck between $15 \%$ to $18 \%$ total out of whole defence budget, at the same time budget share of the Army has increased from 50\% to 55\%. 


\section{$\underline{\text { References }}$}

Book: India's foreign policy retrospect and Prospect (Edited by Sumit Ganguly) https://www.thoughtco.com/look-east-policy-of-india-1435050

Book: Does the Elephant Dance? Contemporary Indian Foreign Policy by David M. Malone

Book: Challenge and Strategy: Rethinking India’s Foreign Policy by Rajiv Sikri https://mea.gov.in/loksabha.htm?dtl/26554/QUESTION_NO_3121_LOOK_EAST_AND_ACT_EAS T_POLICY

https://en.wikipedia.org/wiki/Look_East_policy_(India)

https://economictimes.indiatimes.com/news/politics-and-nation/northeast-statesactive-stakeholders-in-act-east-policy-v-k-singh/articleshow/65092368.cms https://www.jagranjosh.com/general-knowledge/meaning-and-objectives-of-theact-east-policy-of-india-1527251668-1

https://intpolicydigest.org/2018/03/15/india-s-act-east-policy-is-progressingbut-with-a-hangover/

Article: India's Look East Policy: Prospectsand Challenges for Northeast India by Thongkholal Haokip (Studies in Indian Politics) - http://inp.sagepub.com

\section{Mr. Kashyap Kotecha \\ (Assistant Professor (Department of Political Science) \\ Dr.Babasaheb Ambedkar Open University, Ahmedbad, Gujarat \\ \& \\ Dr. Mukesh Khatik \\ Assistant Professor \& H.O.D (Department of Political Science) \\ Gujarat University, Gujarat, Ahmedabad}

